\title{
PENGARUH KECERDASAN EMOSIONAL DAN KECERDASAN SPIRITUAL TERHADAP KEPEMIMPINAN TRANSFORMASIONAL DILIHAT DARI PERSPEKTIF GENDER
}

\author{
Diah Amalia ${ }^{1)}$ \\ Muhammad Ramadhan ${ }^{2)}$ \\ Program Studi Akuntansi Manajerial, Politeknik Negeri Batam \\ Jl. Ahmad Yani, Batam Centre, Batam 29461, Indonesia \\ 1) E-mail: diahamalia@polibatam.ac.id \\ ${ }^{2)}$ E-mail: ramadhanslamet@polibatam.ac.id
}

\begin{abstract}
The research study to examine whether there are significant and positive effects of emotional and spiritual intelligence on transformational leadership of Politeknik Negeri Batam . The research study also examined whether there were differences in emotional, spiritual, and transformational leadership between male and female leaders in Politeknik Negeri Batam. Sample from the research study is 60 samples. 30 samples are active lecturers of the Business Management Department as a representation of a department leader by women, and 30 other samples were active lecturers of the Electrical Department as a representation of a department leader by men. The results of this research study indicate that there are significant and positive effects of emotional intelligence and spiritual intelligence on transformational leadership. There were no significant differences in emotional intelligence, spiritual intelligence, and transformational leadership between male and female leaders.
\end{abstract}

Keywords: Intelligence Emotional, Intelligence Spiritual, Transformational Leadership, Gender 


\section{Pendahuluan}

Pendidikan tinggi merupakan sebuah organisasi. Dalam organisasi pendidikan tinggi pimpinan perguruan tinggi merupakan pimpinan yang bertanggung jawab atas kelangsungan organisasi tersebut. Pendidikan tinggi sebagai organisasi non bisnis harus segera melakukan peningkatan kualitas SDM untuk mencegah agar tidak kalah dalam persaingan. Pendidikan tinggi bertujuan untuk mencerdaskan kehidupan bangsa, sudah tentu tidak hanya cerdas secara intelektual namun lebih penting itu cerdas secara emosional dan cerdas spiritual bagi anak didiknya (Supriyanto, 2012).

Junaidah (2016) menyatakan bahwa Kepemimpinan Pendidikan merupakan kemampuan untuk menggerakkan pelaksanaan pendidikan, sehingga tujuan pendidikan yang telah ditetapkan dapat tercapai secara efektif dan efisien. Kepemimpinan Pendidikan merupakan bagian penting dari manajemen pendidikan yaitu meliputi merencanakan dan mengorganisasi, tetapi peran utama kepemimpinan adalah mempengaruhi orang lain untuk mencapai tujuan yang telah ditetapkan.

Dalam era desentralisasi dan otonomi pendidian, terdapat tiga model kepemimpinan yaitu, kepemimpinan transaksional, kepemimpinan transformasional dan kepemimpinan visioner. Pemimpin dengan kepemimpinan transformasional adalah kepemimpinan yang memilki visi ke depan dan mampu mengidentifikasikan perubahan lingkungan serta mampu mentransformasikan perubahan tersebut kedalam organisasi. Dalam organisasi Pendidikan tinggi pimpinan perguruan tinggi tidak hanya cerdas secara intelektual namun lebih penting itu cerdas secara emosional dan cerdas spiritual.

Menurut Goleman (2015) Kecerdasan Emosional (EQ) pada hakekatnya bertolak pada hubungan antara perasaan, watak, dan naluri, di mana sikap perilaku dalam kehidupan berasal dari kemampuan emosional yang mendasarinya dan para pemimpin secara khusus memerlukan kecerdasan emosional sebab pemimpin tersebut merepresentasikan organisasi kepada masyarakat publik, melakukan interaksi dengan orang-orang di dalam organisasi dan di luar organisasi

Penelitian Khaliq (2011) yang menyatakan semakin tinggi tingkat kecerdasan emosional pimpinan maka akan semakin tinggi pula kepemimpinan transformasionalnya dimana dimensi kecerdasan emosional yang terdiri dari motivasi diri, empati, dan keterampilan sosial, masing-masing berpengaruh signifikan terhadap kepemimpinan transformasional baik secara parsial maupun bersama-sama. Pendapat ini diperkuat oleh penelitian Supriyanto (2012) yaitu Kecerdasan emosional yang meningkat akan berpengaruh terhadap kepemimpinan transformasional. Semakin meningkat tingkat kecerdasan emosional pemimpin, maka kepemimpinan transformasional yang diterapkan akan semakin baik. Hal ini dikarenakan para pemimpin dan manajer secara khusus membutuhkan kecerdasan emosional yang yang baik, karena mereka mewakili organisasi publik.

Dikemukakan Goleman (2015) bahwa kecerdasan intelektual hanya memberikan kontribusi sebesar $20 \%$ sebagai faktor yang mempengaruhi kesuksesan dalam hidup dan $80 \%$ ditentukan oleh kekuatan lainnya. Selain itu, kemampuan intelektual saja tidak akan mampu bekerja dengan baik tanpa diimbangi dengan kecerdasan emosional.

Faktor lain yang penting selain kecerdasan intelektual (IQ) dan kecerdasan emosional (EQ) yaitu kecerdasan spiritual (SQ). Setiawan dan Solimun (2013) pada dasarnya Spiritual Quotient (SQ) adalah kemampuan dasar dari seseorang yang berisikan pengalaman hidup, yang merupakan bagian dari kehidupan seseorang atau bahkan organisasi. Menurut Galvin dalam Supriyanto (2012) bahwa seorang pemimpin harus mempunyai motivasi murni yang berlandaskan nilai-nilai spiritual yang tulus.

Jack Welch dalam Supriyanto (2012) dalam sebuah pidatonya yang dibutuhkan saat ini adalah pemimpin-pemimpin yang memiliki landasan spiritual untuk memimpin sebuah perusahaan. Pemimpin pemimpin yang berhasil membawa perusahaan ke puncak kesuksesan adalah orang-orang yang memiliki integritas, terbuka, mampu menerima kritik, rendah hati, mampu memahami orang lain dengan baik, terinspirasi oleh visi, mengenal diri sendiri dengan 
baik, memiliki spiritualitas yang non dogmatis, dan selalu mengupayakan yang terbaik bagi diri sendiri dan orang lain. Para pemimpin yang sukses lebih mengamalkan nilai-nilai spritual.

Pendapat ini diperkuat lagi oleh Penelitian sebelumnya yang dilakukan oleh Supriyanto (2012) menunjukkan hasil bahwa kecerdasan spiritual (SQ) memiliki pengaruh positif dan signifikan terhadap kepemimpinan transformasional. Hasil ini bermakna bahwa semakin meningkat tingkat kecerdasan spiritual, maka kepemimpinan transformasional akan semakin baik. Koefisien jalur bertanda positif mengindikasikan semakin meningkat tingkat kecerdasan emosional, maka akan mengakibatkan semakin baik pula kepemimpinan transformasional.

Peranan usia, tingkat pendidikan, pengalaman kerja, gender dan kebutuhan untuk berhubungan diprediksi sebagai preferensi ideal pekerja untuk berhubungan dan perilaku kepemimpinan. Kepemimpinan Transformasional dalam perspektif gender menjadi urgen saat ini karena sesuai dengan kebijakan Direktorat Pendidikan Tinggi, dalam mendorong kesetaraan gender dan memberdayakan perempuan dengan cara mengurangi diskriminasi gender dalam seluruh sektor kehidupan, khususnya Sektor Pendidikan.

Hal ini juga menjadi komitmen pemerintah dalam mendukung dan peduli terhadap program Education for All (EFA) dan Millennium Development Goals (MDGs). Powell et al. (2004) dan Lowe \& Galen (1996) dalam Embry, Padgett \& Caldwell (2008) mengemukakan bahwa kepemimpinan transaksional lebih jelek daripada kepemimpinan transformasional, dan kepemimpinan transformasional lebih efektif dari pada kepemimpinan transaksional.

Hasil penelitian Powell (1990) dalam Handriana (2011) menemukan bahwa pemimpin wanita mendapatkan evaluasi lebih rendah ketika menggunakan suatu gaya inkonsistensi gender (gender-inconsistent) (transaksional) dimana pemimpin pria mendapatkan evaluasi lebih tinggi ketika menggunakan suatu gaya inkonsistensi gender (transformasional), sebab gaya transformasional dilihat lebih positif dari pada gaya transaksional. Jadi dari penelitian ini, tidak jelas apakah pengaruh penggunaan gaya inkonsistensi gender terhadap pemimpin pria dan wanita (Embry, Padgett \& Caldwell, 2008).

Berdasarkan kesimpulan dari hasil penelitian yang sudah dilakukan oleh peneliti terdahulu masih terdapat celah penelitian ( gap research) terkait dengan pengujian variabel kecerdasan emosional dan kecerdasan spiritual terhadap kepemimpinan transformasional dilihat dari perspektif gender yang akan dicoba dijawab melalui penelitian ini.

Permasalahan yang dapat dirumuskan dalam penelitian ini yaitu bagaimana pengaruh kecerdasan emosional dan kecerdasan spiritual terhadap kepemimpinan transformasional pejabat politeknik negeri batam dilihat dari perspektif gender.

\section{Kajian Teori, Literatur, dan Pengembangan Hipotesis}

\subsection{Kajian Teori}

Kecerdasan emosional adalah kemampuan merasakan, memahami, dan secara efektif menerapkan daya dan kepekaan emosi sebagai sumber energi, informasi, koneksi, dan pengaruh yang manusiawi (Cooper,2001). Menurut Bitsch (2008) indikator yang termasuk dalam variabel kecerdasan emosional ada 7 (tujuh) indikator tersebut diukur dengan "The Yong emotional intelligence Inventory (EQI)", yakni kuisioner self-report yang mengukur 7 indikator tersebut adalah: 1) Intrapersonal skills, 2) Interpesonal skills, 3) Assertive, 4) Contentment in life, 5) Reselience, 6) Self-esteem, 7) Self-actualization.

Kecerdasan Spiritual (SQ), merupakan temuan terkini secara ilmiah,yang pertama kali digagas oleh Danah Zohar dan Ian Marshall. Danah Zohar dan Ian Marshall dalam Ginanjar (2008) mendefenisikan kecerdasan spiritual sebagai kecerdasan untuk menghadapi persoalan makna atau value, yaitu kecerdasan untuk menempatkan perilaku dan hidup kita dalam konteks makna yang lebih luas dan kaya, kecerdasan untuk menilai bahwa tindakan atau jalan hidup seseorang lebih bermakna di bandingkan dengan lain 
SQ adalah landasan yang diperlukan untuk memfungsikan IQ dan EQ secara efektif. Bahkan SQ merupakan kecerdasan tertinggi kita (Danah Zohar dan Ian Marshall, "SQ:Spiritual Intellegence", Bloomsbury, Great Britain). Zohar dan Marshall (2000) dalam Srivastava, A dan Misra, S. (2012) mengklaim bahwa kecerdasan spiritual dibudidayakan melalui jiwa dan bukan otak. Spiritual Quotient dapat menyembuhkan luka seseorang dan melengkapi keberadaan seseorang. Kecerdasan spiritual melampaui akal sadar dan melampaui ego. Kecerdasan semacam ini tidak ada hubungannya dengan masyarakat atau budaya mana yang menentukan. Sebagai gantinya, ia menganjurkan untuk memasuki intuisi dan/atau rasa makna kita yang dalam.

Bila spiritual quotient (SQ) telah berkembang dengan baik, maka gambaran atau ciri-ciri orang yang memiliki kecerdasan spiritual (SQ) tinggi menurut Zohar dan Marshall (2007) dalam Supriyanto, 2012 yakni: a. Adaptif secara spontan dan aktif; b. Kesadaran diri; c. Melakukan perubahan dimana terbuka terhadap perbedaan; d. Memiliki visi dan misi; e. Berpendangan holisitik; f. Refleksi diri; g. Sumber Inspirasi.

Sukidi 2002 dalam Arya 2016, mengemukakan tentang nilai - nilai dari kecerdasan spiritual berdasarkan komponen - komponen dalam Kecerdasan Spiritual (SQ) yang banyak dibutuhkan dalam dunia bisnis : a. Mutlak Jujur; b. Keterbukaan; c. Pengetahuan diri; d. Fokus pada konstribusi; e. Spiritual non dogmatis

Konsep awal tentang kepemimpinan transformasional telah dimulai sejak Burns (1978) dalam Khilmiyah (2015), menjelaskan kepemimpinan transformasional sebagai suatu proses yang pada dasarnya "para pemimpin dan pengikut saling menaikkan diri ke tingkat moralitas dan motivasi yang lebih tinggi”. Para pemimpin tersebut mencoba menimbulkan kesadaran dari pengikut dengan menyerukan cita-cita yang lebih tinggi dan nilai-nilai moral seperti kemerdekaan, keadilan, dan kemanusiaan; bukan didasarkan atas emosi, seperti misalnya keserakahan, kecemburuan atau kebencian.

Pemimpin transformasional sesungguhnya merupakan agen perubahan, karena memang erat kaitannya dengan transformasi yang terjadi dalam suatu organisai. Fungsi utamanya adalah berperan sebagai katalis perubahan, bukannya sebagai pengontrol perubahan. Seorang pemimpin transformasional memiliki visi yang jelas, memiliki gambaran holistik tentang bagaimana organisasi di masa depan ketika semua tujuan dan sasarannya telah tercapai (Covey, 1989).

Empat dimensi dari gaya kepemimpinan transformasional (Bass \& Avolio, 1994: 4-7) dalam Khilmiyah, 2015 adalah : a.Idealized influence; b. Inspirational motivation; c. Intellectual stimulation; d.Individualize consideration.

Berdasarkan hasil kajian literatur yang dilakukan Robbins dan Judge (2009: 453) dalam Khilmiyah, 2015 menyimpulkan bahwa seseorang yang dapat menampilkan kepemimpinan transformasional ternyata dapat menginspirasi bawahannya lebih meningkatkan kemampuan dirinya dan memberikan pengaruh yang sangat kuat terhadap bawahannya.

Gender adalah elemen dasar dari konsep diri kita. Mengetahui bahwa "aku adalah wanita" atau "Aku adalah pria" adalah bagian inti dari identitas personal kita. Orang sering memandang dirinya punya minat dan kepribadian yang sesuai dengan gendernya. Kebanyakan teori-teori kepemimpinan tidak hanya menolak peran perempuan, tetapi juga mengalami bias gender dan terbentuk asumsi yang tidak benar tentang peran gender dalam organisasi.

Menurut Tony Bush, (2006:95) dalam Khilmiyah (2015) Kebanyakan teori hanya memfokuskan pada peran laki-laki dalam organisasi. Perempuan di banyak negara hanya berperan sebagai pengajar saja, dan relatif hanya sedikit yang memiliki posisi penting pemegang otoritas dalam sejumlah sekolah menengah maupun di perguruan tinggi.

Deaux \& Kite (1993) dalam Taylor, Shelley., Et al (2009) Gender Stereotype adalah keyakinan tentang atribut personal pria dan wanita. Penekanannya di sini adalah pada gender sebagai karakteristik dari target pembentukan kesan. Riset menunjukkan bahwa keyakinan tentang ciri khas pria dan wanita dapat mempengaruhi persepsi kita terhadap seseorang dan 
menyebabkan bias dalam evaluasi kita terhadap kinerja orang itu.

Manifestasi ketidakadilan gender dalam kepemimpinan yang paling mencolok adalah pandangan stereotype gender yang dikaitkan dengan kepemimpinan. Kebanyakan kaum laki-laki dalam paham manajemen senior menciptakan sebuah image yang menjurus pada pengabdian kepada dirinya sendiri (self pertuating). Stereotype tersebut dipertegas dengan asumsi yang tidak benar bahwa kepemimpinan adalah sebuah karakteristik laki-laki yang memerlukan kekerasan fisik dan mental serta kemampuan untuk mendekati kesulitan-kesulitan dengan tanpa emosional.

Kemampuan manajemen dan kepemimpinan perempuan dapat dibuktikan dari keberhasilan perempuan dalam menunaikan perannya dalam masyarakat, dan peran manajemen tersebut merupakan indikator keberhasilan peran perempuan.

Masyarakat juga berkeyakinan bahwa perempuan sosok yang kurang tampil sebagai sosok besar yang memiliki kharisma, tetapi perempuan diakui lebih teliti dari laki-laki. Karena itu, masyarakat tambah yakin kalau perempuan itu lebih pantas untuk bersikap patuh menjadi orang yang dipimpin, bukan menjadi pemimpin. Aspek-aspek kepemimpinan dan manajemen yang dipandang 'feminin' ini sama dengan aspek kepemimpinan yang saat ini dipandang efektif. Aspek kepemimpinan feminin ini telah dipraktekkan oleh kebanyakan perempuan yang menduduki posisi pemimpin yakni model kepemimpinan yang memberdayakan orang lain dan sangat mampu berkomunikasi dengan staf dan mahasiswa. Model kepemimpinan semacam ini adalah model kepemimpinan transformasional dan edukatif.

\subsection{Kajian Literatur}

Eka Putra (2012) menunjukkan bahwa terdapat pengaruh yang signifikan antara kecerdasan emosional dengan kepemimpinan transformasional pada PT. Bank Danamon Cab Panglima Polim, Jakarta dimana kecerdasan emosional yang baik akan menuntun individu untuk bekerja dengan optimal dan pimpinan PT. Bank Danamon menunjukkan bahwa beliau memiliki hubungan yang baik dengan para pegawainya. Hasil penelitian Supriyanto (2012) mempertegas bahwa Kecerdasan emosional memiliki pengaruh positif dan signifikan terhadap kepemimpinan transformasional. Hasil ini bermakna bahwa semakin meningkat tingkat kecerdasan emosional, maka kepemimpinan transformasional akan semakin baik.

Hasil penelitian di lapangan mendukung pendapat dari Goleman (2000) yang menyatakan bahwa "para manajer dan pemimpin, secara khusus membutuhkan kecerdasan emosional yang tinggi karena mereka mewakili organisasi kepada publik, mereka berinteraksi dengan banyak orang didalam dan diluar organisasi dan mereka membentuk moral karyawan". Para pemimpin dengan empatinya mampu memahami kebutuhan para bawahannya dan memberikan feedback kepada mereka".

Hasil penelitian untuk Kecerdasan Spiritual memiliki pengaruh positif dan signifikan terhadap kepemimpinan transformasional. Hasil ini bermakna bahwa semakin meningkat tingkat kecerdasan spiritual, maka kepemimpinan transformasional akan semakin baik. Seorang pemimpin haruslah mempunyai tingkat keimanan dan ketakwaan yang tinggi, sehingga memahami bahwa kemampuan memimpin yang ia miliki adalah pemberian Tuhan. Dan sebagai manusia mempunyai kelebihan dan kekurangan. Ia harus berusaha dan menyandarkan usahanya pada sang Pencipta dengan penuh tawakal. Pemimpin mendapat amanah yang harus dipertanggungjawabkan kepada-Nya. Dengan demikian, setiap pemimpin memiliki dua amanah, yakni amanah dari organisasi dan amanah dari Tuhannya. Kesadaran spiritualitas ini memberi corak kepemimpinan yang sangat berketuhanan dan manusiawi, dia akan membawa organisasinya ke arah visi dan ketuhanan, bukan ke arah keserakahan. Pemimpin dengan kesadaran spiritual akan menumbuhkan rasa tanggung jawab pada sesama manusia dan Tuhannya.

Asmadi dkk (2015), menemukan dalam penelitiannya bahwa kepemimpinan transformasional terbukti bukan sebagai variabel moderator. Akan tetapi, kehadiran kepemimpinan transformasional tidak 
menyebabkan dampak negatif terhadap kinerja karyawan, namun justru ikut memberikan kontribusi positif terhadap kinerja karyawan, artinya pada perusahaan PT. Garam (Persero) ciri kepemimpinan transformasional telah hadir, namun kepemimpinan tersebut belum mampu memberikan pengaruh terhadap potensi kecerdasan emosional dan kecerdasan spiritual. Hal ini merupakan informasi yang sangat bermanfaat dan penting bagi perusahaan bahwa untuk mencapai kinerja yang tinggi dan meningkatkan pencapaian tujuan utama tidak hanya mengandalkan kecerdasan intelektual semata, tapi perlu melibatkan secara aktif kecerdasan emosional dan kecerdasan spiritual.

Hasil penelitian-penelitian masalah gender, umumnya menunjukkan tidak banyak perbedaan gender dalam hal organisasi. Namun jika gender dihubungkan dengan gaya kepemimpinan terlihat adanya gaya tertentu khas perempuan, tapi bukan karena perbedaan jenis kelamin, namun lebih pada faktor karakteristik/tuntutan pekerjaan (Steers, Porter \& Bigley 1996 dalam Zulinda 2011). Karakteristik atau tuntutan pekerjaan dapat mempengaruhi gaya kepemimpinan perempuan yaitu feminim-maskulin, feminim-transaksional, maskulin-transformasional, dan transaksional-transformasional.

Burke dan Collins (2001) dalam Dhyan (2015) melaporkan hasil kajiannya bahwa perempuan mungkin lebih bisa menunjukkan bahwa mereka menggunakan sebuah gaya kepemimpinan interaktif dibanding laki-laki, yang disebut Kepemimpinan Tranformasional. Gaya kepemimpinan ini sangat berhubungan dengan tujuh skill manajemen secara umum yaitu (1) pendelagasian, (2) manajemen konflik, (3) coaching dan developing, (4) personal organization dan time management, (5) komunikasi, (6) adaptabilitas personal, serta (7) analisa masalah dan pengambilan keputusan.

Berbeda dari hasil penelitian Tjahyo (2007) menunjukkan bahwa pada PT. Multiplastjaya Tatamandiri Sidoarjo sebagai Objek penelitian, terdapat perbedaan yang signifikan antara persepsi bawahan terhadap gaya kepemimpinan transformasional antara pemimpin laki-laki dan pemimpin perempuan dan dalam penelitian di temukan bahwa menurut persepsi bawahan, pemimpin laki-laki lebih memiliki gaya kepemimpinan transformasinal dibandingkan dengan pemimpin perempuan.

Berdasarkan hasil penelitian Wiyono 2011, juga menunjukkan bahwa tidak terdapat perbedaan yang sangat signifikan dalam keenam dimensi kemampuan kepemimpinan tranformasional kepala sekolah pria dan wanita SMP di Kodya Yogyakarta yang meliputi: (1) Kemampuan menyelesaikan masalah, (2) Kemampuan membantu mengembangkan kepemimpinan guru, (3) Kemampuan membangun komitmen guru untuk perubahan, (4) Kemampuan menciptakan suatu kondisi untuk pertumbuhan pengetahuan dan ketrampilan profesional guru, (5) Kemampuan mengembangkan kepemimpinan untuk pembelajaran organisasi, dan (6) Kemampuan memelihara keseimbangan emosi.

Menurut Millati, 2013 Dinamika relasi gender di kalangan civitas akademik belum sepenuhnya pada taraf responsif gender, adapun keterwakilan beberapa perempuan untuk menjabat pada posisi tertentu bukan semata-mata telah mengaplikasikan konsep gender secara utuh, namun hal tersebut ditunjang beberapa faktor diantaranya ketersediaan SDM kaitannya dengan kepangkatan yang dirasa minim pada dosen perempuan. Sekalipun secara umum, tingkat kepemimpinan didominasi oleh laki-laki, namun tidak ada aturan yang menghambat perempuan. Peluang jabatan diberikan kepada laki-laki dan perempuan secara penuh.

\subsection{Hipotesis}

Berdasarkan uraian kajian teori dan kajian literatur di atas, maka hipotesis yang akan diuji sebagai berikut:

$\mathrm{H}_{1}$ : Kecerdasan emosional memiliki pengaruh positif signifikan terhadap kepemimpinan transformasional

$\mathrm{H}_{2}$ : Kecerdasan spiritual memiliki pengaruh positif signifikan terhadap kepemimpinan transformasional

$\mathrm{H}_{3}$ : Ada perbedaan Kecerdasan Emosional antara Pemimpin Laki-Laki dan Perempuan

$\mathrm{H}_{4}$ : Ada perbedaan Kecerdasan Spiritual antara 
Pemimpin Laki-Laki dan Perempuan

$\mathrm{H}_{5}$ : Ada perbedaan Kepemimpinan Transformasional antara Pemimpin Laki-Laki dan Perempuan

\section{Metode Penelitian}

Jenis data dalam penelitian ini adalah data kuantitatif, Sedangkan Sumber yang digunakan adalah data primer. Sumber data primer yang diperoleh dalam penelitian ini adalah berasal dari lokasi penelitian yaitu melalui pembagian angket atau kuesioner (daftar pertanyaan kepada responden).

Teknik pengumpulan data yang dipergunakan oleh peneliti melalui penyebaran kuisioner. Instrumen dalam penelitian ini akan diukur dengan menggunakan skala Likert. Dalam skala Likert, responden akan diberikan pertanyaan/pernyataan dengan beberapa alternatif jawaban yang dianggap paling tepat oleh responden yang terdiri dari lima pilihan jawaban, yaitu: Sangat Tidak Setuju (skor 1), Tidak Setuju (skor 2), Netral (skor 3), Setuju (skor 4), dan Sangat Setuju (skor 5).

Penggunaan skala Likert dalam penelitian ini terkait dengan penelitian mengenai sikap, menurut Sugiyono (2003: 15). Selanjutnya dikatakan bahwa data-data yang diperoleh dari pengukuran instrumen sikap dengan skala Likert adalah data yang berskala interval.

Teknik penarikan sample menggunakan metode pengambilan sampel tidak acak yaitu purposive judgment sampling atau pengambilan sampel menggunakan kriteria khusus. Populasi yang diambil adalah jurusan manajemen bisnis Polibatam sebagai perwakilan pemimpin perempuan dan jurusan elektro Polibatam sebagai perwakilan pemimpin laki-laki. Sampel yang diambil adalah dosen aktif jurusan manajemen bisnis sebanyak 30 orang dan dosen aktif jurusan elektro sebanyak 30 orang. Pengolahan data pada penelitian ini menggunakan SPSS versi 21.

Analisis data pada penelitian ini menggunakan pengujian validitas dan realibilitas. Uji validitas merupakan jika pertanyaan pada suatu kuesioner mampu untuk mengungkapkan sesuatu yang akan diukur oleh kuesioner tersebut. Uji signifikansi dilakukan dengan membandingkan nilai $r$ hitung dengan $r$ tabel, jika $r_{\text {hitung }}>r_{\text {tabel }}$ dan nilai positif maka instrumen tersebut dinyatakan valid (Ghozali, 2012). Uji reliabilitas merupakan jika jawaban seseorang terhadap pertanyaan adalah konsisten atau stabil dari waktu ke waktu (Santoso, 2002). Suatu instrumen dinyatakan reliabel bila koefisien reliabilitas minimal 0,6 (Sugiyono, 2014).

Dalam penggunaan metode regresi linier berganda, secara teoretis akan menghasilkan nilai parameter model penduga yang sah apabila dilakukan pengujian asumsi klasik. Asumsi klasik terdiri dari multikolinierits, autokorelasi, heterokedastisitas, dan normalitas. Kemudian dilakukan analisis regresi linear berganda untuk menganalisis pengaruh antara beberapa variabel independen (X) dengan variabel dependen (Y). Adapun persamaan matematis regresi linear berganda, apabila diaplikasikan dalam penelitian adalah sebagai berikut :

$$
\mathbf{Y}=\mathbf{a}+\mathbf{b}_{1} \mathbf{X}_{1}+\mathbf{b}_{2} \mathbf{X}_{2}+\mathbf{e}
$$

Dimana :

a $=$ Konstanta

b1-b2 = Koefisien regresi variabel $\mathrm{X}_{1}-\mathrm{X}_{2}$ (parameter)

$\mathrm{Y}=$ Kepemimpinan Transformasional

$\mathrm{X}_{1} \quad=$ Kecerdasan Emosional

$\mathrm{X}_{2}=$ Kecerdasan Spiritual

e $\quad=$ Kesalahan pengukuran (standard error)

Uji hipotesis dilakukan dengan menggunakan analisis regresi berganda dengan menggunakan uji $\mathrm{t}$ (parsial) dan uji independen sample $\mathrm{t}$ test. Uji $\mathrm{t}$ bertujuan untuk menguji signifikasi konstanta dari setiap variabel bebas terhadap variabel terikat, seperti di kemukakan Sugiyono (2003:184). Pengujian ini dilakukan dengan cara membandingkan $t_{\text {hitung }}$ dengan nilai $t_{\text {tabel }}$. Apabila $t_{\text {hitung }}>t_{\text {tabel }}$ dengan tingkat signifikasi dibawah 0,05 (5\%), maka secara individu (parsial) variabel bebas berpengaruh signifikan terhadap variabel terikat, begitu juga sebaliknya. Uji independen sample $\mathrm{t}$ test bertujuan untuk mengetahui apakah terdapat perbedaan antara satu grup dengan grup lainnya (Pratisto, 2005). Grup yang dijadikan uji beda merupakan sampel grup yang bebas. Artinya, kedua grup tidak saling berhubungan. Apabila $t_{\text {hitung }}>t_{\text {tabel, }}$ 
maka terdapat perbedaan yang signifikan antara dua grup yang berbeda.

\section{Hasil dan Pembahasan}

\subsection{Pengolahan Data Kuesioner 4.1.1 Uji Validitas}

Berdasarkan pada tabel 4.1, item pertanyaan pada variabel independen kecerdasan emosional $\left(\mathrm{X}_{1}\right)$ mulai dari pertanyaan 1 sampai 15 dinyatakan valid. Hal tersebut dikarenakan nilai $r_{\text {hitung }}>r_{\text {tabel }}$.

Tabel 4.1 Hasil Validitas Variabel Kecerdasan Emosional

$\left(\mathrm{X}_{1}\right)$

\begin{tabular}{|l|c|c|c|}
\hline \multicolumn{1}{|c|}{ Item } & r hitung & r tabel & Keterangan \\
\hline $\mathrm{X} 1.1$ & 0,657 & 0,254 & Valid \\
\hline $\mathrm{X} 1.2$ & 0,743 & 0,254 & Valid \\
\hline $\mathrm{X} 1.3$ & 0,831 & 0,254 & Valid \\
\hline $\mathrm{X} 1.4$ & 0,926 & 0,254 & Valid \\
\hline $\mathrm{X} 1.5$ & 0,895 & 0,254 & Valid \\
\hline $\mathrm{X} 1.6$ & 0,863 & 0,254 & Valid \\
\hline $\mathrm{X} 1.7$ & 0,79 & 0,254 & Valid \\
\hline $\mathrm{X} 1.8$ & 0,847 & 0,254 & Valid \\
\hline $\mathrm{X} 1.9$ & 0,692 & 0,254 & Valid \\
\hline $\mathrm{X} 1.10$ & 0,925 & 0,254 & Valid \\
\hline $\mathrm{X} 1.11$ & 0,938 & 0,254 & Valid \\
\hline $\mathrm{X} 1.12$ & 0,903 & 0,254 & Valid \\
\hline $\mathrm{X} 1.13$ & 0,694 & 0,254 & Valid \\
\hline $\mathrm{X} 1.14$ & 0,722 & 0,254 & Valid \\
\hline $\mathrm{X} 1.15$ & 0,938 & 0,254 & Valid \\
\hline
\end{tabular}

Sumber: Hasil Olah Data Peneliti

Berdasarkan pada tabel 4.2, item pertanyaan pada variabel independen kecerdasan spiritual $\left(\mathrm{X}_{2}\right)$ mulai dari pertanyaan 1 sampai 5 dinyatakan valid. Hal tersebut dikarenakan nilai $r_{\text {hitung }}>r_{\text {tabel }}$.

Tabel 4.2 Hasil Validitas Variabel Kecerdasan Spritual ( $\left.\mathbf{X}_{2}\right)$

\begin{tabular}{|l|c|c|c|}
\hline Item & $\mathbf{r}$ hitung & $\mathbf{r}$ tabel & Keterangan \\
\hline $\mathrm{X} 2.1$ & 0,928 & 0,254 & Valid \\
\hline $\mathrm{X} 2.2$ & 0,920 & 0,254 & Valid \\
\hline $\mathrm{X} 2.3$ & 0,651 & 0,254 & Valid \\
\hline $\mathrm{X} 2.4$ & 0,841 & 0,254 & Valid \\
\hline X2.5 & 0,730 & 0,254 & Valid \\
\hline
\end{tabular}

Berdasarkan pada tabel 4.3 , item pertanyaan pada variabel dependen kepemimpinan transformasional (Y) mulai dari pertanyaan 1 sampai 12 dinyatakan valid. Hal tersebut dikarenakan nilai $r_{\text {hitung }}>r_{\text {tabel }}$.
Tabel 4.3 Hasil Validitas Variabel Kepemimpinan Transformasional (Y)

\begin{tabular}{|l|c|c|c|}
\hline \multicolumn{1}{|c|}{ Item } & r hitung & $\mathbf{r}$ tabel & Keterangan \\
\hline $\mathrm{X} 1.1$ & 0,876 & 0,254 & Valid \\
\hline $\mathrm{X} 1.2$ & 0,874 & 0,254 & Valid \\
\hline $\mathrm{X} 1.3$ & 0,851 & 0,254 & Valid \\
\hline $\mathrm{X} 1.4$ & 0,892 & 0,254 & Valid \\
\hline $\mathrm{X} 1.5$ & 0,925 & 0,254 & Valid \\
\hline $\mathrm{X} 1.6$ & 0,813 & 0,254 & Valid \\
\hline $\mathrm{X} 1.7$ & 0,862 & 0,254 & Valid \\
\hline $\mathrm{X} 1.8$ & 0,880 & 0,254 & Valid \\
\hline $\mathrm{X} 1.9$ & 0,893 & 0,254 & Valid \\
\hline $\mathrm{X} 1.10$ & 0,656 & 0,254 & Valid \\
\hline $\mathrm{X} 1.11$ & 0,858 & 0,254 & Valid \\
\hline $\mathrm{X} 1.12$ & 0,831 & 0,254 & Valid \\
\hline
\end{tabular}

Sumber: Hasil Olah Data Peneliti

\subsubsection{Uji Reliabilitas}

Berdasarkan pada tabel 4.4, baik variabel kecerdasan emosional $\left(\mathrm{X}_{1}\right)$, kecerdasan spiritual $\left(\mathrm{X}_{2}\right)$, maupun kepemimpinan transformasional (Y) memiliki nilai Cronbach's Alpha (SPSS) di atas 0,6. Hal tersebut menandakan bahwa pertanyaan yang ada dalam setiap variabel sudah reliabel.

Tabel 4.4 Hasil Uji Reliabilitas Variabel

\begin{tabular}{|c|c|c|c|}
\hline Variabel & Cronbach's Alpha (SPSS) & Cronbach's Alpha (Minimum) & Keterangan \\
\hline $\mathrm{X} 1$ & 0,967 & 0,6 & Reliabel \\
\hline $\mathrm{X} 2$ & 0,866 & 0,6 & Reliabel \\
\hline $\mathrm{Y}$ & 0,965 & 0,6 & Reliabel \\
\hline
\end{tabular}

Sumber: Hasil Olah Data Peneliti

\subsubsection{Uji Asumsi Klasik}

\section{A. Uji Multikolinearitas}

Berdasarkan pada tabel 4.5 , nilai masing-masing VIF pada variabel kecerdasan emosional (X1) dan kecerdasan spiritual (X2) adalah 4,554 dan 4,554. Artinya, Nilai tersebut di atas 10 yang bermakna tidak terdapat masalah multikolinearitas.

\section{Tabel 4.5 Hasil Uji Multikolinearitas}

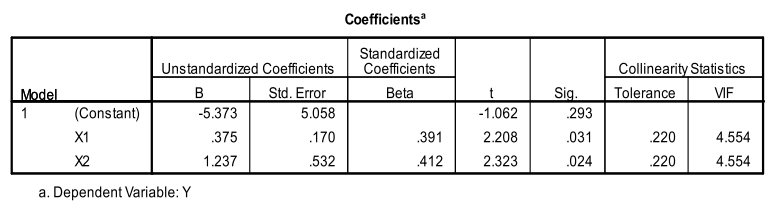

Sumber: Hasil Olah Data Peneliti 


\section{B. Uji Heteroskedastisitas}

Pada uji heteroskedastisitas akan digunakan metode uji Glejser. Berdasarkan pada tabel 4.6, nilai masing-masing Sig. (SPSS) pada variabel kecerdasan emosional $\left(\mathrm{X}_{1}\right)$ dan kecerdasan spiritual $\left(\mathrm{X}_{2}\right)$ adalah 0,195 dan 0,428. Artinya, Nilai tersebut di atas 0,05 yang bermakna tidak terdapat masalah heteroskedastisitas.

\section{Tabel 4.6 Hasil Uji Heteroskedastisitas}

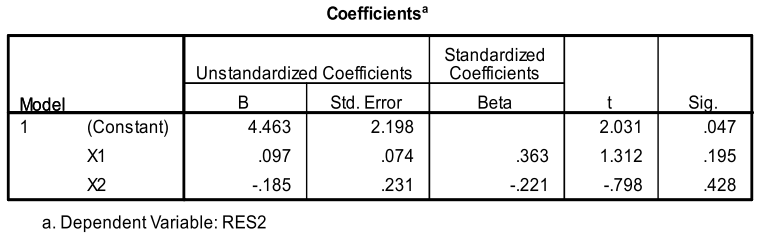

Sumber: Hasil Olah Data Peneliti

\section{Uji Normalitas}

Pada uji normalitas akan digunakan metode Kolmogorov Smirnov. Berdasarkan pada tabel 4.7, nilai masing-masing Asymp. Sig. (2-tailed) pada variabel kecerdasan emosional $\left(\mathrm{X}_{1}\right)$, kecerdasan spiritual $\left(\mathrm{X}_{2}\right)$, dan kepemimpinan transformasional $(\mathrm{Y})$ adalah 0,190, 0,074, dan 0,313. Artinya, Nilai tersebut di atas 0,05 yang bermakna data terdistribusi secara normal.

\section{Tabel 4.7 Hasil Uji Normalitas}

\begin{tabular}{|c|c|c|c|c|}
\hline \multicolumn{5}{|c|}{ One-Sample Kolmogorov-Smirnov Test } \\
\hline & & $\mathrm{X} 1$ & $\mathrm{X}_{2}$ & Y \\
\hline $\mathrm{N}$ & & 60 & 60 & 60 \\
\hline \multirow[t]{2}{*}{ Normal Parameters ${ }^{a, b}$} & Mean & 58.82 & 19.68 & 41.03 \\
\hline & Std. Deviation & 12.209 & 3.895 & 11.704 \\
\hline \multirow[t]{3}{*}{ Most Extreme Differences } & Absolute & .140 & .166 & .124 \\
\hline & Positive & .093 & .111 & .084 \\
\hline & Negative & -.140 & -.166 & -.124 \\
\hline Kolmogorov-SmirnovZ & & 1.084 & 1.284 & .962 \\
\hline Asymp. Sig. (2-tailed) & & .190 & .074 & .313 \\
\hline
\end{tabular}

Sumber: Hasil Olah Data Peneliti

\subsection{Analisis Regresi Linear Berganda}

Penelitian ini menggunakan analisis regresi linear berganda. Variabel independennya, yaitu kecerdasan emosional $\left(\mathrm{X}_{1}\right)$ dan kecerdasan spiritual $\left(\mathrm{X}_{2}\right)$, sedangkan variabel dependennya, yaitu kepemimpinan transformasi (Y). Berikut hasil analisis regresi linear berganda.

Tabel 4.8 Hasil Analisis Regresi Linear Berganda

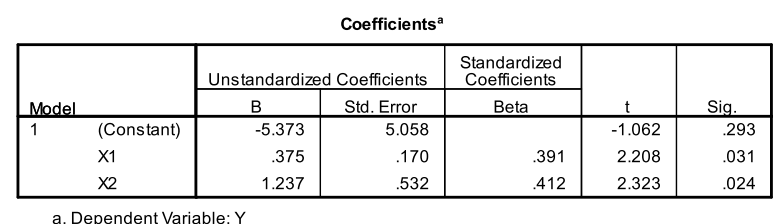

Sumber: Hasil Olah Data Peneliti

Berdasarkan pada tabel 4.8, dapat diperoleh persamaan regresi linear berganda sebagai berikut:

$$
\mathrm{Y}=-5,373+0,375 \mathrm{X} 1+1,237 \mathrm{X} 2+\mathrm{e}
$$

\subsection{Pengujian Hipotesis}

\subsubsection{Hipotesis 1}

Berdasarkan table 4.9, nilai $t_{\text {hitung }}$ adalah 2,208. Nilai tersebut lebih besar dibandingkan $t_{\text {tabel }}$. Selain itu, nilai Sig. (SPSS) menunjukkan angka positif 0,031 yang berarti bahwa nilai tersebut di bawah nilai signifikansi 0,05. Kedua indikasi tersebut menandakan bahwa hipotesis 1 diterima. Artinya, kecerdasan emosional berpengaruh positif signifikan terhadap kepemimpinan transformasional.

Tabel 4.9 Hasil Uji t $X_{1}$ terhadap Y

\begin{tabular}{|c|c|c|c|c|}
\hline Variabel & B & t hitung & t tabel & Sig. \\
\hline $\mathrm{X} 1$ & 0,375 & 2,208 & 2,00247 & 0,031 \\
\hline
\end{tabular}

Sumber: Hasil Olah Data Peneliti

\subsubsection{Hipotesis 2}

Berdasarkan table 4.10, nilai $t_{\text {hitung }}$ adalah 2,323. Nilai tersebut lebih besar dibandingkan $t_{\text {tabel }}$. Selain itu, nilai Sig. (SPSS) menunjukkan angka positif 0,024 yang berarti bahwa nilai tersebut di bawah nilai signifikansi 0,05. Kedua indikasi tersebut menandakan bahwa hipotesis 2 diterima. Artinya, kecerdasan spiritual berpengaruh positif signifikan terhadap kepemimpinan transformasional.

Tabel 4.10 Hasil Uji t X2 terhadap Y

\begin{tabular}{|c|c|c|c|c|}
\hline Variabel & B & t hitung & t tabel & Sig. \\
\hline $\mathrm{X} 2$ & 1,237 & 2,323 & 2,00247 & 0,024 \\
\hline
\end{tabular}

Sumber: Hasil Olah Data Peneliti 


\subsubsection{Hipotesis 3}

Berdasarkan table 4.11, nilai Sig. (2-tailed) adalah 0,510. Nilai tersebut di atas dari nilai signifikansi 0,05 yang mengakibatkan hipotesis 3 tidak diterima. Artinya, tidak ada perbedaan secara signifikan kecerdasan emosional antara pemimpin laki-laki dan perempuan.

Tabel 4.11 Hasil Uji Independent Sample t Test Kecerdasan Emosional Pemimpin Laki-Laki dan Perempuan

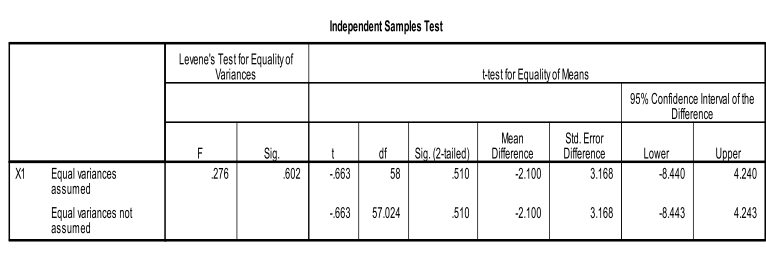

Sumber: Hasil Olah Data Peneliti

\subsubsection{Hipotesis 4}

Berdasarkan table 4.12, nilai Sig. (2-tailed) adalah 0,819. Nilai tersebut di atas dari nilai signifikansi 0,05 yang mengakibatkan hipotesis 4 tidak diterima. Artinya, tidak ada perbedaan secara signifikan kecerdasan spiritual antara pemimpin laki-laki dan perempuan.

Tabel 4.12 Hasil Uji Independent Sample t Test Kecerdasan Spiritual Pemimpin Laki-Laki dan Perempuan

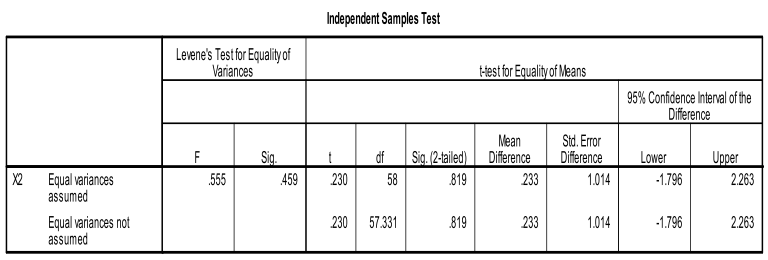

Sumber: Hasil Olah Data Peneliti

\subsubsection{Hipotesis 5}

Berdasarkan table 4.13, nilai Sig. (2-tailed) adalah 0,394. Nilai tersebut di atas dari nilai signifikansi 0,05 yang mengakibatkan hipotesis 5 tidak diterima. Artinya, tidak ada perbedaan secara signifikan kepemimpinan transformasional antara pemimpin laki-laki dan perempuan.

Tabel 4.13 Hasil Uji Independent Sample t Test Kepemimpinan Transformasional Pemimpin Laki-Laki dan Perempuan

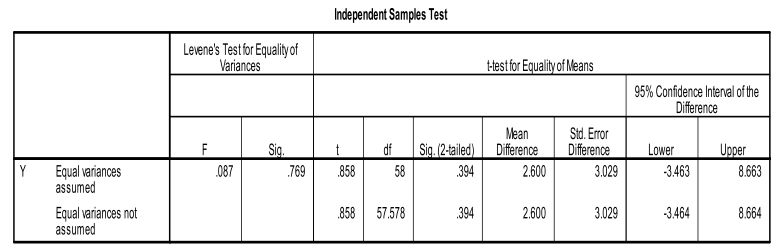

Sumber: Hasil Olah Data Peneliti

\subsection{Analisis Data}

Uji hipotesis dilakukan dengan menggunakan analisis regresi berganda dengan menggunakan uji $\mathrm{t}$ (parsial) dan uji independen sample t

Tabel 4.14 Ringkasan Hasil Uji Hipotesis

\begin{tabular}{|c|c|c|c|}
\hline \multicolumn{2}{|r|}{ Hipotesis } & Sig. & Kesimpulan \\
\hline $\mathrm{H}_{1}$ & $\begin{array}{l}\text { Kecerdasan } r \text { emosional } \\
\text { berpengaruh positif signifikan } \\
\text { terhadap kepemimpinan } \\
\text { transformasional }\end{array}$ & 0,031 & Diterima \\
\hline $\mathrm{H}_{2}$ & $\begin{array}{l}\text { Kecerdasan spiritual } \\
\text { berpengaruh positif signifikan } \\
\text { terhadap kepemimpinan } \\
\text { transformasional }\end{array}$ & 0,024 & Diterima \\
\hline $\mathrm{H}_{3}$ & $\begin{array}{lrr}\text { Terdapat } & \text { perbedaan } \\
\text { kecerdasan } & \text { emosional } & \text { antara } \\
\text { pemimpin } & \text { laki-laki } & \text { dan } \\
\text { perempuan } & & \\
\end{array}$ & 0,510 & $\begin{array}{c}\text { Tidak } \\
\text { diterima }\end{array}$ \\
\hline $\mathrm{H}_{4}$ & \begin{tabular}{llr} 
Terdapat & \multicolumn{2}{r}{ perbedaan } \\
kecerdasan & spiritual & antara \\
pemimpin & laki-laki & dan \\
perempuan & &
\end{tabular} & 0,819 & $\begin{array}{c}\text { Tidak } \\
\text { diterima }\end{array}$ \\
\hline $\mathrm{H}_{5}$ & $\begin{array}{lr}\text { Terdapat } & \text { perbedaan } \\
\text { kepemimpinan } & \\
\text { transformasional antara } \\
\text { pemimpin laki-laki dan } \\
\text { perempuan }\end{array}$ & 0,394 & $\begin{array}{c}\text { TIdak } \\
\text { diterima }\end{array}$ \\
\hline
\end{tabular}

Sumber: Hasil Olah Data Peneliti

\subsubsection{Pengaruh Kecerdasan Emosional terhadap} Kepemimpinan Transformasional

Berdasarkan hasil pengujian, terdapat pengaruh signifikan kecerdasan emosional terhadap kepemimpinan transformasional. Kedua variabel tersebut berhubungan positif. Artinya, semakin tinggi kecerdasan emosional, kepemimpinan transformasional akan semakin baik. Hasil penelitian ini sama dengan penelitian yang dilakukan oleh Salih, Khafaji, dan Mohsen (2016) bahwa terdapat pengaruh 
kecerdasan emosional signifikan dan positif terhadap kepemimpinan transformasional. Hal ini menandakan bahwa seorang pemimpin yang memiliki kecerdasan emosional yang tinggi mampu menerapkan kepemimpinan transformasional. Seorang pemimpin yang memiliki kecerdasan emosional yang tinggi mampu dengan mudah untuk mengekspresikan perasaannya dan meningkatkan rasa tanggungjawab pada personilnya melalui komunikasi yang baik sehingga dapat meningkatkan motivasi personil untuk mencapai tujuan organisasi.

\subsubsection{Pengaruh Kecerdasan Spiritual terhadap Kepemimpinan Transformasional}

Berdasarkan hasil pengujian, terdapat pengaruh signifikan kecerdasan spiritual terhadap kepemimpinan transformasional. Kedua variabel tersebut berhubungan positif. Artinya, semakin tinggi kecerdasan spiritual, kepemimpinan transformasional akan semakin baik. Hasil penelitian ini sama dengan penelitian yang dilakukan oleh Alam (2014) bahwa terdapat pengaruh kecerdasan spiritual signifikan dan positif terhadap kepemimpinan transformasional. Hal ini menandakan bahwa seorang pemimpin perlu memiliki kecerdasan spiritual dalam menerapkan kepemimpinan transformasional. Menurut Galvin dalam Ginanjar (2007) seorang pemimpin harus memiliki motivasi yang berlandaskan nilai-nilai spiritual sehingga ia mampu untuk memberikan pengaruh kepada personilnya dalam menerapkan kepemimpinan transformasional.

\subsubsection{Perbedaan Kecerdasan Emosional antara Pemimpin Laki-Laki dan Perempuan}

Berdasarkan hasil pengujian, tidak ada perbedaan signifikan kecerdasan emosional antara pemimpin laki-laki dan perempuan. Hasil penelitian ini sama dengan penelitian yang dilakukan oleh Gamage dan Dhanapala (2013) bahwa tidak ada perbedaan signifikan kecerdasan emosional antara pemimpin laki-laki dan perempuan. Hal ini menandakan bahwa pemimpin baik laki-laki maupun perempuan memiliki peran dan fungsi yang sama. Misalnya, ketika laki-laki ataupun perempuan berperan sebagai pemimpin dalam suatu organisasi kualitas kerja tidak ditentukan oleh gender, tetapi lebih mengarah kepada motivasi pribadi seorang pemimpin untuk memajukan organisasi. Oleh sebab itu, pemimpin laki-laki dan perempuan memiliki kesempatan yang setara dalam mengembangkan kecerdasan emosionalnya.

\subsubsection{Perbedaan Kecerdasan Spiritual antara Pemimpin Laki-Laki dan Perempuan}

Berdasarkan hasil pengujian, tidak ada perbedaan signifikan kecerdasan spiritual antara pemimpin laki-laki dan perempuan. Hasil penelitian ini serupa dengan penelitian Nodehi dan Nehardani (2013) bahwa tidak ada perbedaan signifikan kecerdasan spiritual laki-laki dan perempuan. Hal ini menandakan bahwa kecerdasan spiritual bukanlah didominasi oleh satu gender saja, melainkan bisa dimiliki oleh laki-laki dan perempuan secara setara.

\subsubsection{Perbedaan Kepemimpinan Tranformasional antara Pemimpin Laki-Laki dan Perempuan}

Berdasarkan hasil pengujian, tidak ada perbedaan signifikan kepemimpinan transformasional antara pemimpin laki-laki dan perempuan. Hasil penelitian ini serupa dengan penelitian Judeh (2010) bahwa tidak ada perbedaan signifikan kepemimpinan transformasional antara pemimpin laki-laki dan perempuan. Hal ini menandakan bahwa baik laki-laki maupun perempuan memiliki kesamaan terhadap kepemimpinan transformasional mereka sehingga tidak ada isu terkait perbedaan gender dalam menerapkan kepemimpinan transformasional. 


\section{Kesimpulan dan Saran}

\subsection{Kesimpulan}

Berdasarkan hasil pengolahan data antara variabel $\mathrm{X}$ dan variabel $\mathrm{Y}$ dapat di tarik kesimpulan sebagai berikut:

a. Terdapat pengaruh kecerdasan emosional signifikan dan positif terhadap kepemimpinan transformasional

b. Terdapat pengaruh kecerdasan spiritual signifikan dan positif terhadap kepemimpinan transformasional

c. Tidak ada perbedaan signifikan kecerdasan emosional antara pemimpin laki-laki dan perempuan

d. Tidak ada perbedaan signifikan kecerdasan spiritual antara pemimpin laki-laki dan perempuan

e. Tidak ada perbedaan signifikan kepemimpinan transformasional antara pemimpin laki-laki dan perempuan.

\subsection{Saran}

Bagi penelitian selanjutnya diharapkan menambah variabel lain di dalam pengujiannya, seperti budaya organisasi. Sementara bagi Polibatam, diharapkan agar memberikan kesempatan yang setara baik laki-laki maupun perempuan dalam mengembangkan potensi baik kecerdasan emosional dan spiritual dalam penerapan kepemimpinan transformasional.

\section{Daftar Pustaka}

Alam, Shahram. 2014. The Relationship between Spiritual Intelligence and Transformational Leadership in Sports Managers. Bulletin of Environment, Pharmacology and Life Sciences Vol 3 (Spl issue IV) 2014: Hal. 01-05

Arya Erlangga M. 2016. Pengaruh Kecerdasan Emosional Dan Kecerdasan Spiritual Pada Kepuasan Kerja Yang Berdampak Terhadap Kinerja. Jurnal Universitas Islam Indonesia. Yogyakarta
Asmadi didi, Syairudin.B, Widodo.E. 2015. Kontribusi Kecerdasan Emosional Dan Kecerdasan Spiritual terhadap Kinerja Karyawan Yang Dimoderasi Kepemimpinan

Transformasional. Prosiding Seminar Nasional Manajemen Teknologi XXII, ITS.

Bitsch, V. 2008. Spirituality and Religion Developments in the management literature Relevant to agribusiness and Entrepreneurship? Annual World and symposium of the International Food and agribusiness Management Association. bitsch@msu.edu.

Cooper Robert K, Sawaf Ayman, 2001, EXECUTIVE EQ Kecerdasan Emosional dalam kepemimpinan dan Organisasi, Penerbit PT Gramedia Pustaka Utama Jakarta

Dhyan Ryani Parashakti. 2015. Perbedaan Gaya Kepemimpinan Dalam Perspektif Maskulin dan Feminin Jurnal Ilmiah Manajemen dan Bisnis Volume 1, Nomor 1, Maret 2015. Universitas Mercu Buana

Eka Putra, Prasetyo. 2012. Pengaruh Kecerdasan Emosional Terhadap Kepemimpinan Transformasional Pada PT Bank Danamon Kantor Cabang Panglima Polim. Skripsi Fisip UI

Embry, Andrew, Margaret Y. Radgett, Craig B. Caldwell. 2008. Can Leader Step Outside of The GenderBox? An Examination of Leadership Gender Role Stereotyps, Journal of Leadership, Vol. 15, No. 1:30-45

Gamage, P.N. dan Dhanapala, R.E. 2013. Leadership

Styles and Emotional Intelligence of

Managirial Level Employees in

Telecommunication. International Journal of Social Science \& Interdisciplinary Research, Vol. 2 (6), Juni (2013): Hal. 10-23

Ginanjar Agustian Ary, 2008, The New Edition

Rahasia Sukses Membangun Kecerdasan Emosi dan Spiritual ESQ Emotional Spiritual Quotient, Penerbit Arga

Golemen, D. 2015. Emotional Intellegent: Kecerdasan 
Emosional, Mengapa EI lebih penting dari

$I Q$. Penerbit Gramedia Pustaka Utama, Jakarta, Cetakan keduapuluh.

Ghozali, I. 2012. Aplikasi Analisis Multivariate dengan Program IBM SPSS 20. Semarang: Badan Penerbit Universitas Diponegoro

Hidayat, Anwar. 2014. Pilihan Uji Normalitas Berdasarkan Software-Jumlah Sampel. Diakses tanggal 5 Maret 2018 dari statistikian.com:

https://www.statistikian.com/2014/08/pili han-uji-normalitas-univariate.html

Judeh, Mahfuz. 2010. Transformational Leadership: A Study of Gender Differences in Private Universities. International Review of Business Research Papers Volume 6. Number 4. September 2010. Hal. 118 - 125

Junaidah, 2016. Kepemimpinan Transformasional Dalam Pendidikan Vol 6 No.2, Al-Idarah : Jurnal Kependidikan Islam

Khaliq Pangabdi, Lugas. 2011. Pengaruh Kecerdasan Emosional Terhadap Kepemimpinan Transformasional (Studi pada RS.dr.Iskak, Tulungagung). SKRIPSI Jurusan Manajemen - Fakultas Ekonomi UM

Khilmiyah Akif. 2015. Kepemimpinan Transformasional Berkeadilan Gender: Konsep dan Implementasi di Madrasah. Penerbit Samudra Biru (Anggota IKAPI), Yogyakarta

Mandell, B. \& Pherwani, S.2003. Relationship Between Emotional Intelligence and Transformational Leadership Style: A Gender Comparison. Journal of Business and Psychology 17: 387

Maulana Khulqi, Putra dan Saptoto Ridwan. 2017. Peran Kecerdasan Emosi Dan Kecerdasan Spiritual Terhadap Kepemimpinan Transformasional Pada Pimpinan Organisasi Kemahasiswaan Universitas Gadjah Mada, Universitas Gadjah Mada, Yogyakarta

Millati Faizah, Erma. 2013. Manajemen Kepemimpinan di Perguruan Tinggi Islam
(Studi Analisis Potret Kesetaraan Gender di STAIN Ponorogo), El-Wasathiya: Jurnal Studi Agama,

Naro, Wahyuddin. 2015. Artikulasi Kesetaraan Jender dalam Pendidikan (Perspektif Islam). Jurnal Diskursus Islam Vol. 3 No. 2: 311-328

Nodehi, H., Nehardani, H. 2013. Relation between Spiritual Intelligence and Job Satisfaction. Journal of Social Issues \& Humanities, 1(5), 67-72.

Parashakti, R.D. 2015. Perbedaan Gaya Kepemimpinan dalam Perspektif Maskulin Dan Feminin. Jurnal Ilmiah Manajemen dan Bisnis Volume 1, Nomor 1: 92-101

Pianda, Didi. 2018. Kinerja guru: kompetensi guru, motivasi kerja dan kepemimpinan kepala sekolah. Bojonggenteng: CV Jejak

Pratisto, Arif. 2005. Cara Mudah Mengatasi Masalah Statistik dan Rancangan Percobaan dengan SPSS 12. Jakarta: PT Elex Media Komputindo Republik Indonesia. 2012. Undang-Undang No. 12 Tahun 2012 tentang Pendidikan Tinggi.Jakarta: Sekretariat Negara.

Salih, M.S., Khafaji, N.A., dan Mohsen, A.B. 2016. Impact of Emotional Intelligence on Transformational Leadership in Ali'kha Industrial Establishment. International Journal of Current Research Vol 8, Issue 05: Hal. 32231-32236

Santoso, S. 2002. Buku Latihan SPSS Satistik Parametrik. Jakarta: Elex Media Komputindo.

Setiawan, M, Solimun. 2013. Kecerdasan Emosional dan Kecerdasan Spiritual Pengaruhnya terhadap Kepusan Kerja dan Kinerja Karyawan (Studi di Lembaga Penjamin Mutu Pendidikan (LPMP) Nusa Tenggara Barat). Jurnal Aplikasi manajemen. Vol. 11 (4):Hal.629-639

Silva, D dan Mendis, B. 2017. Male vs Female Leaders: Analysis of Transformational, Transactional \& Laissez-faire Women Leadership Styles. European Journal of 
Business and Management Vol.9, No.9, 2017:

Hal. 19-26

Srivastava, A dan Misra, S. (2012). IS Spiritual Quotient A Better Tool Os Success: Spirituality In The New World Order. International Journal of Multidisciplinary Management Studies, Vol. 2, No. 1, pp. 256-266.

Sugiyono, 2003, Statistik Untuk Penelitian, Alfabeta, Bandung

Sugiyono. 2014. Metode Penelitian Manajemen. Bandung: Alfabeta.

Supriyanto, Achmad Sani dan Eka Afnan Troena. 2012. Pengaruh Kecerdasan Emosional dan Kecerdasan Spiritual terhadap Kepemimpinan Transformasional, Kepuasan Kerja dan Kinerja Manajer (Studi di bank Syari'ah Kota Malang). Jurnal Aplikasi Manajemen Volume 10 Nomor 4 Desember 2012 hal 692-709

Tarmizi, Rosmiaty., Dewantoro, G, S, Suwandi. 2012. Pengaruh kecerdasan Emosional dan kecerdasan spiritual Terhadap kinerja Auditor Kantor Badan Pengawasan Keuangan Wilayah Lampung, Jurnal Akuntansi Keuangan. Vol.3. hal 39-54

Taylor, Shelley E., Et al, 2009, Psikologi Sosial, Edisi Kedua Belas, Penerbit Kencana, Jakarta

Thibodeaux, W. 2018. These Are the Groups Most Likely to Steal from Your Company, According to New Survey. Diakses tanggal 5 September 2018 dari inc.com: https://www.inc.com/wanda-thibodeaux/1-th ese-are-groups-most-likely-to-steal-from-you r-company-according-to-new-survey.html

Tjahyo Tri Purnomo dan Purnawati Susanti. 2007. Analisis Perbedaan Persepsi Bawahan Terhadap Pada PT. Multiplastjaya Tatamandiri Sidoarjo. Universitas Wijaya Kusuma, Surabaya.

Wiyono Giri. 2011. Kepemimpinan Transformasional Kepala Sekolah Berbasis Gender di SMP
Kodya Yogyakarta. Experiment/Research eprints.uny.ac.id

Zulida Nina Situmorang. 2011. Gaya Kepemimpinan Perempuan. Proceeding PESAT (Psikologi, Ekonomi, Sastra, Arsitektur \& Sipil). Universitas Gunadarma. 